\title{
Chinese Economics, 1976-1986: Basic Trends and Perspectives
}

ERHARD LOUVEN

Institute of Asian Affairs, Hamburg

Everyone travelling through the People's Republic of China nowadays and comparing the situation with that of 1976, becomes well aware of the great changes that have been taking place since then. In the countryside, the peasants are building new houses, often two-storied and in the urban areas, one sees people dressed after the latest Western fashions.

\section{Statistical Evidence of Change}

The impressionistic perception is supported by the official statistics the Chinese are publishing to an ever increasing extent since about 1979. In Tables 1 to 3 , the author compares the fourth five-year plan (1971-1975) with the sixth five-year plan (1981-1985), i.e. the last period of the Mao era and the most recently completed plan period of the Deng era. Of course, one has to bear in mind that official Chinese statistics can be grossly misleading, but one has to work with them and certain images they give can be corrected through other approaches, for example, case-studies. A first rough evaluation of these figures will most probably deliver the first clues to crucial fields, where more indepth surveys are needed.

Table 1 indicates that in terms of growth rates of the main sectors there was a big upswing. The growth rate of light industry increased whereas that of heavy industry decreased, but in both cases this was intended by the economic planners. One question ensuing from this would be: was it really possible to readjust the two branches of industry?

Table 2 deals with the main so-called economic proportions. A big change can be noticed with respect to the division of productive and non-productive accumulation, in Western terms, investment. During the fourth plan the proportion of accumulation allocated to the non-productive sector amounted only to $24.5 \%$, during the sixth plan period this proportion was almost one half of total accumulation. Did this have implications regarding the service sector? Is the service sector really regarded as an equal partner of the traditional pro- 
Table 1. Main Economic Indicators of the 4th and 6th Five-Year Plan Periods (Comparison of Growth Rates)

\begin{tabular}{lrr}
\hline & 4th Plan & 6th Plan \\
\hline Total product of society & 7.3 & 10.8 \\
1970: $403.1,1975: 573.8$ & & \\
1980: $853.7,1985: 1,426.1$ & & \\
& & \\
Gross output value of agriculture and industry" & 7.7 & \\
1970: $424.3,1975: 616.2$ & & \\
1980: $908.6,1985: 1,525.3$ & & \\
of which & 4.0 & \\
- gross agricultural output value & & \\
1970: $166.3,1975: 202.1$ & & \\
1980: $259.1,1985: 444.9$ & 9.1 & \\
- gross industrial output value & & \\
1970: $787.1,1975: 1,218.8$ & 7.7 \\
1980: $1,888.9,1985: 3,147.9$ & & \\
* light industry & & \\
1970: $515.6,1975: 748.4$ & 10.2 & \\
1980: $1,259.5,1985: 2,221.1$ & & \\
${ }^{*}$ heavy industry & & \\
1970: $1,290.2,1975: 2,093.8$ & & \\
1980: $3,036.4,1985: 4,808.4$ & & \\
National Income & & \\
1970: $249.7,1975: 284.7$ & & \\
1980: $515.9,1985: 823.0$ & & \\
\hline
\end{tabular}

a. Calculated with 1952 as base year, equal to 100 ; the index numbers for 1985 were calculated on the basis of the growth rates for 1984/1985.

Sources: Zhongguo Tongji Nianjian 1985 (Beijing 1985); Xinhua, February 28, 1986, as quoted in Summary of World Broadcasts (SWB), FE/8197/C/1-9, March 3, 1986.

ductive sectors? The proportion of agriculture of the combined gross output value only slightly increased from $31.1 \%$ to $33.8 \%$ in the assessed periods. Is agriculture, or more generally the countryside, better off than the urban areas?

The problems mentioned in the last paragraph lead us to Table 3. A first glimpse shows us that the average annual per capita wage of staff and workers in state-owned units from 1978 until 1985 approximately doubled, while the per capita income of peasants almost tripled. There is clear evidence that income from collective operations decreased, while income from household production increased and in 1984 contributed approximately $80 \%$ of the total income of the peasants. But has the standard of living of the peasants really undergone such a quick improvement? 
Table 2. Proportions of Main Economic Indicators of the 4th and 6th FiveYear Plans (in percent)

\begin{tabular}{lcr}
\hline & 4th Plan & 6 th Plan \\
\hline Agriculture $^{\mathrm{a}}$ & 31.1 & 33.8 \\
& & \\
Industry $^{\mathrm{a}}$ & 68.9 & 66.2 \\
- light industry & 43.6 & 48.9 \\
- heavy industry & 56.4 & 51.1 \\
& & \\
Consumption $^{\mathrm{b}}$ & 67.0 & 70.5 \\
- personal consumption & 90.0 & 88.2 \\
- public consumption & 10.0 & 11.8 \\
& & \\
Accumulation & & 29.5 \\
- productive & 33.0 & 51.0 \\
- non-productive & 75.5 & 49.0 \\
& 24.5 & \\
- fixed assets & & 77.9 \\
- circulating funds & 72.5 & 22.1 \\
\hline a. Calculated as the arithmetic mean of the individual years of the whole plan period. b. As \\
a., but only for the years 1981-1984. & & \\
Source: Zhongguo Tongji Nianjian 1985 (Beijing 1985). & & \\
\hline
\end{tabular}

Table 3. Development of Income of Peasants and Workers and Staff in Stateowned Units, 1976-1985 (in Yuan)

\begin{tabular}{lrrrrrr}
\hline Year & $(1)$ & $(2)$ & $(3)$ & $(3 a)$ & $(3 b)$ & $(3 \mathrm{c})$ \\
\hline 1971 & 597 & & & & & \\
1972 & 622 & & & & & \\
1973 & 614 & & & & & \\
1974 & 622 & & & & & \\
1975 & 613 & & & & & \\
1976 & 605 & & & & & \\
1977 & 602 & & & & & \\
1978 & 644 & & 133.57 & 88.53 & 35.79 & 9.25 \\
1979 & 705 & & 160.17 & 101.97 & 44.00 & 14.20 \\
1980 & 803 & & 191.33 & 108.37 & 62.55 & 20.41 \\
1981 & 812 & 500.4 & 223.44 & 116.20 & 84.52 & 22.72 \\
1982 & 836 & 535.3 & 270.11 & 58.09 & 187.55 & 24.47 \\
1983 & 865 & 572.9 & 309.77 & 36.06 & 244.88 & 28.17 \\
1984 & 961 & 660.1 & 355.33 & 35.33 & 282.85 & 31.17 \\
1985 & 1.142 & 752.0 & 397.00 & & & \\
\hline
\end{tabular}

(1) Average annual wage of staff and workers in state-owned units.

Sources: Zhongguo Tongji Nianjian 1981 (Beijing 1982); Zhongguo Tongji Nianjian 1985 
(Beijing 1985); Renmin Ribao, January 12, 1986; Xinhua, February 28, 1986, quoted in SWB, FE/8197/C/9, March 3, 1986.

(2) Yearly income per capita in cities according to a sample survey.

Sources: Zhongguo Tongji Nianjian 1983 (Beijing 1983); Zhongguo Tongji Nianjian 1983 (Beijing 1985); Xinhua, February 28, quoted in SWB, FE/8197/C/8, March 3, 1986.

(3) Yearly net income per capita of peasant households according to a sample survey.

Sources: Zhongguo Tongji Nianjian 1983 (Beijing 1983); Zhongguo Tongji Nianjian 1985 (Beijing 1985); Xinhua, February 28, 1986, quoted in SWB, FE/8197/C/8, March 3, 1986. (3a) Of which: income from the collective.

Sources: as (3).

(3b) Net income from household production.

Sources: as (3).

(3c) Other non-borrowed incomes.

Sources: as (3).

\section{Structural Deficiencies and Shortcomings of Mao-type Economy}

China's economic system at the end of the Mao period was overcentralized and overplanned. Growth had been achieved through extensive investments. Because of inefficiency and waste there was no real increase in living standards. Bottlenecks, shortages and serious imbalances were omnipresent. Energy shortages frequently idled the productive apparatus. Partially processed goods were in short supply in some places and excess production was being warehoused in other places. According to official sources, in mid-1978 the products stockpiled in storage amounted to 200 billion Yuan equalling half the annual industrial output value of the entire economy of the country. ${ }^{1}$ Large parts of capital stock were obsolete, and total factor productivity was declining. Thus, for example, in the period of 1976-1978 labour productivity of full-time workers and employees in the state-owned industrial enterprises only increased $1.7 \%$ annually as against $8.7 \%$ during the first five-year plan period (1953-1957). ${ }^{2}$

Production of both agricultural and light industrial goods fell short of the needs both in terms of quantity and quality. Underemployment and unemployment were common features. Educational and research institutions were in a shambles, and because of the isolation during the cultural revolution and the 'mass strategy' pursued in these fields China had fallen far behind the advanced countries. 
To cite John Unger, until Mao's death the peasantry had been required to experiment with agricultural techniques totally unsuited to local conditions. The peasants had been committed to labour during the slack seasons for little pay on commune and country public work projects of no direct benefit to them. The size of the private plots and the privately organized pig and poultry raising had repeatedly been reduced. The peasants had been forced to raise grain even on fields unsuited to grain raising. ${ }^{3}$

A centralized system, such as existed during the time of the cultural revolution, where market relations do not operate, can only function at a low level of economic development. In this stage the division of labour, specialization, and the smooth exchange of goods are not important. The moment a substantial increase in productivity becomes the unavoidable prerequisite for industrial growth, in other words the moment the socio-economic level as a whole is to be raised, this concept is no longer applicable. ${ }^{4}$ The same applies to the external economic relations.

In the following sector-wise comments on the reform the author attempts to gain evidence from micro-level or macro-level studies in order to be able to isolate developments or facts that might have adverse effects on the reform in the long run. If only a macro-level analysis had been used there might have emerged a tendency in the findings that could give a wrong impression.

\section{Agricultural and Rural Problems}

\section{Reform Measures and their Effects}

Evidence suggests that there had been no master plan to reform agriculture, no deliberate effort from above to steer all of rural China down a single path. ${ }^{5}$ The reform process represents a complex and somewhat erratic interaction between top and bottom levels of the bureaucratic structure. This finally led to an almost complete abandonment of the commune system, which had reached its heyday during the cultural revolution.

The reform was initiated by Zhao Ziyang and Wan Li in Sichuan and Anhui. In 1979 and 1980 some leading organs of the Chinese press claimed that only some $10 \%$ of the villages which were the most impoverished and backward would ever adopt the new systems that meant a departure from the collectivist system of the commune. ${ }^{\circ}$ By early 1984 newspapers reported that more than $90 \%$ of the agricultural production teams had decided to decollec- 
tivize into the new responsibility system, i.e. into family-operated smallholdings. ${ }^{7}$

Unger's survey of twenty-eight villages in several provinces suggests that, had the decision been the peasants' to make, many communities might well have stopped short of dividing the collective property to such an extent. ${ }^{8}$ Decollectivization took place county-wise, i.e. new regulations were issued uniformly in one county, whereas other sets of new regulations were released in other counties.

The responsibility system in the countryside, like similar experiments in the past, has increased production significantly. This can be demonstrated by macro-data such as, for example, that presented in Table 1. One might suggest that, as a weak point in the development sequence, regional differentials might occur. But statistical analysis shows us that, against conventional belief, nearly every province, irrespective of its former backward or top position, could experience considerable success, particularly in grain production. ${ }^{9}$ In terms of grain production during the time between 1979 and 1984 only the provinces of Guangxi (3.8\%), Gansu (8.2\%), and Hebei (9.8\%) experienced an aggregated growth per capita of less than $10 \%$. Those provinces which showed internal achievement differentials until the late 1970s could experience growth rates considerably higher than the average rates. This applies both to grain production and to total agrarian value creation.

Especially the provinces of Sichuan and Anhui have to be mentioned because they were understood as crisis areas and the agricultural reform was initiated there. Sichuan with a population of more than 100 million was, with an agrarian value creation of 197 Yuan per capita in 1984, below the national average of 215 Yuan, but the growth rate for the time period of 1979-1984 amounted to $72.8 \%$. Furthermore, the province became a top area in grain production (1984: $403 \mathrm{~kg}$ per capita; national average $394 \mathrm{~kg}$ ). Similar figures can be given for Anhui: agrarian value creation of 220 Yuan per capita in 1984; growth rate in grain production of $36.2 \%$ in $1979-1984$, grain production per capita in 1984 of $432 \mathrm{~kg} .{ }^{10}$

The relatively rapid growth in these former crisis provinces can of course be attributed to the efforts of dynamic and energetic provincial leaders. Another strand of explanation might be that quick success could be achieved in places where the deficiencies and shortcomings of the old system were especially grave. Certainly, further detailed studies are necessary to have clear insights into these developments.

The decollectivization into millions of family smallholdings meant a chal- 


\section{Table 4. Income of Members and Cadres of Liuhe Production Brigade,} 1979 and 1980

\begin{tabular}{lrr}
\hline & 1979 & 1980 \\
$\begin{array}{lr}\text { 1. Members of brigade (number) } \\
\text { 2. Brigade cadres, peasant-teachers etc. (number) }\end{array}$ & 1,304 & $(1,265)$ \\
$\begin{array}{l}\text { 3. Yearly income of cadres in non-productive work points } \\
\text { (tongchou gongfen) }\end{array}$ & 53,710 & 42 \\
$\begin{array}{l}\text { 4. Yearly income of cadres in Yuan } \\
\text { (line 3 multiplied by 0.8) }\end{array}$ & 42,968 & 3,264 \\
$\begin{array}{l}\text { 5. Average contribution to income of cadres by each } \\
\text { brigade member in Yuan (line 4 divided by line 1) }\end{array}$ & 32.95 & 2.58 \\
$\begin{array}{l}\text { 6. Grain deliveries to cadres (total in kg) } \\
\text { 7. Average contribution to grain deliveries by each } \\
\text { brigade member (line 6 divided by line 1) }\end{array}$ & 92,992 & - \\
\hline
\end{tabular}

Liuhe Production Brigade is located in Tanhe commune, Xinyang county, Henan province. Source: New China News Agency (NCNA), August 25, 1981, quoted in SWB, FE/6814/ BII, September 29, 1981.

lenge to some strata of the rural bureaucracy. Before the reform, cadres of production brigades and teams had the authority to bring pressure to bear against the ordinary brigade or team members. Now the new systems of production responsibility loosened the cadres' permanent supervision. Some considerable numbers of cadres were released from their posts and transferred to normal agricultural work again. The following table shows the effects of reform concerning income in a production brigade in Henan province.

A break-down of the cadres as to administrative, teaching or medical functions is not known. It can be assumed that some of these services had certainly to be paid privately by the peasants. But the heavy burden of cost paid for over-administration was taken off their shoulders.

It is understandable that the cadres thus released and become powerless -covertly or openly - are in opposition against the reform. But there is another stratum of cadres usually of higher rank which seems to accomodate relatively smoothly to the new system. Numerous cases have become known of alliances between "new elements", i.e. rich peasants, and cadres. ${ }^{11}$ The peasants contribute'donations' such as money for schools or other infrastructural institutions, whereas the cadres, especially such powerful cadres who continue to control the allocation of dozens of sorts of permits and who control access to most of the village-owned resources and property, bring in their 'political relations'. Such relations can be instrumental in providing favours to the rich peasantry. Whether or not this 'antagonistic cooperation' becomes a normal thing in the villages or counties remains to be seen. 
Of course, there are strata of the rural population who are not included in this new patronage network and therefore are worried about the new systems. First, there are families with a large number of dependents, elderly people without relatives to care for them, imcomplete families and families with ill or disabled members. Under the old collectivist system, these people used to receive free grain and a minimum supply within the framework of the "five guarantees". The individualistic attitude of a large quantity of the farmers, particularily the rich ones, has strengthened their reluctance to cooperate with their weaker neighbours. The old safety net has been widely destroyed, and new social security systems such as for instance insurance systems will take decades to operate effectively.

Secondly, there are households having no reserves which, for some reason or other, are not competitive. Technological inputs are expensive, and it is far from clear whether many smallholders can raise the necessary capital. They might be driven off their plots and run into debts, if a crop fails. One solution for these people and particularly people from disadvantaged hinterland areas could be hired labour. The wages or more generally the income might be higher than under the old system. But should a large migration from the disadvantaged areas into the well-to-do areas take place, the wages could be levelled. Furthermore problems of exploitation could occur. The authorities in Beijing plan to foster so-called central towns in the countryside and to develop them into small industrial centres.

Estimates are available on the employment effects of the new systems. The enormous rural population could not continue to improve their living standards on the tiny plots. It is openly admitted by certain Chinese planners that only $30 \%$ to $40 \%$ of the peasant households could make their living on the existing croplands. ${ }^{12}$ Xue Muqiao went as far as to say that "once agriculture is modernized, it will need only a few dozen million people at the most.instead of the present 300 million if production remains on the same scale. This means more than 200 million people waiting for jobs, which will have to be found in new fields of production." ${ }^{\prime 3}$

The land/man ratio is constantly decreasing. On June 22, 1986 the Beijing paper Jingjixue Zhoubao carried an article on the drastic decrease of farmland in the country. ${ }^{14}$ According to this source, the farmland per capita fell from $2.59 \mathrm{mu}$ in 1957 to $1.57 \mathrm{mu}$ in 1977 , a decrease of $39 \%$. During the sixth fiveyear plan period (1981-1985) China annually lost 7.377 million mu of farmland on average, an annual rate of decrease of $0.5 \%$. In Heilongjiang province the farmland per capita was $8.4 \mathrm{mu}$ in 1977, the figure now is $4 \mathrm{mu}$. The re- 
spective figures for other provinces were as follows: Anhui $19773 \mathrm{mu}, 1982$ $1.6 \mathrm{mu}$; Guangdong $19771.5 \mathrm{mu}$, now $0.78 \mathrm{mu}$; Zhejiang $19771.5 \mathrm{mu}$, now $0.7 \mathrm{mu}$; Sichuan $19772 \mathrm{mu}$, now less than $1 \mathrm{mu}$. During 1985 the farmland in Shandong decreased by 1.87 million $\mathrm{mu}$, that of Xinjiang by 1.706 million $\mathrm{mu}$ and that of Guangdong by 1.010 million mu. The farmland in these six provinces and one autonomous region decreased by 7.910 million $\mathrm{mu}$ in all.

Among the main reasons for the drastic decrease in farmland are: I. The state and townships have occupied a large area of farmland for their construction purposes. II. The speed of the peasants' occupation of land for building houses has become very high. III. Soil erosion has decreased farmland. China's current area of eroded soil is about between 1.1 million and 1.5 million $\mathrm{km}^{2}$, accounting for between one-eight and one-sixth of the country's territory. One reason for the upsetting of ecological balance is the arbitrary felling of forests. IV. Sideline production has occupied more farmland.

On the one hand, farmland is lost because of erosion and non-agricultural use of land mainly by industrial enterprises. In the course of industrialization, competition for land will grow between agriculture and industry. On the other hand, the law of diminishing returns seems to apply to agriculture. This is especially true for the agrarian top areas of China. Though the technical optimum in the increase of land productivity has evidently not yet been reached, one seems to have come near the optimal point in economic terms, ${ }^{15}$ though the latter criterion might be subject to the arbitrary fixing of price relations and other reference items.

The disintegration of the old collectivist social security system and the rationale of the new responsibility systems ("many hands mean wealth") tend to have adverse effects on population control policy in the countryside.

As a sort of flanking measure the economic decision makers in Beijing decreed considerable purchase price increases for agricultural products. Besides supporting the reform, these increases were meant to stop the development of the internal terms of trade between industry and agriculture to the disadvantage to the latter. In terms of the "absolute scissors differential between agriculture and industry" a maximum value to the disadvantage of the peasants was reached in $1975 .{ }^{16}$ Only in 1982 the state prevailing in 1957 had again been reached. In other words: from 1957 until 1975 the peasants had to work longer each year for a certain quantity of industrial products; only after 1978 a significant improvement of the price relationship occurred.

In the course of agricultural reform the prices were increased by $20 \%$ for quota grain and by $70 \%$ for above-quota grain. The state undertook to buy 
some 50 to 60 million tons of grain at guaranteed prices. This resulted in a huge increase in the subsidies which had to be paid to agriculture. The amount of subsidies in the state budget increased sharply especially after 1984. This result of the reform policy is called "subsidies trap" because thriving agricultural production compels the state to pay more and more subsidies so that the resources for industrial modernization are reduced.

\section{Repercussions of Agricultural Reform on the Whole National Economy}

The central authorities in Beijing, after the death of Mao Zedong, facing a grim economic and social situation, initiated agricultural reform by means of a big decision in the realm of Ordnungspolitik (systemic policy). We have to leave the question unanswered whether there was a master plan or just an experiment in the beginning which was made nationwide afterwards. One aim of this decision seemed to be to disengage the state from the day-to-day burdens of interventionist policies in order to have ample manoeuvring room for modernization work in the industrial, urban, sector. Thus the central authorities tried to leave investments, control and organization tasks to the lower level authorities in the countryside. A side aim was to minimize the so-called economic transaction costs of the reform for the modern sector of economy and society.

As we know by now, the original scheme did not work fully. The state had frequently to intervene. Considering the state of the agriculture, considerable growth rates are possible only on the basis of infrastructural work. In the past a large proportion of infrastructure projects (irrigation, dams, roads, etc.) had been implemented by means of campaigns, i.e. voluntary and low-paid or even non-paid mass labour of millions of people. Chinese economists call this phenomenon "labour accumulation". Machetzki estimates that in the pre-reform era 20 days per man-year were dedicated to infrastructural projects. Taking a work force of 250 million people this would mean a total of 5 billion of work days per year. ${ }^{17}$

Future agricultural development will largely depend upon technological improvements, i.e. more mechanized irrigation systems, better supply of artificial fertilizer and strains of seed. It is an open question whether or not the agricultural system as a subsystem of the economy will be in a position to propel the needed growth independently. It is more likely that the state will be, at some time in the future, compelled to allocate considerable investments into agriculture. For the time being the results of agriculture and the improvement of the standard of living of most of the peasants are promising. But these suc- 
cesses may to a large extent stem from the fact that the gravest deficiencies and shortcomings of the old system have been removed and that the individualistic motivation was set free.

As productive yields reach a plateau level, there will most probably be an increase in state intervention in the agricultural sector. Possibly this will be connected with more and more control devolving on party and state cadres. A consequence could be that then more and more features of the old system will re-emerge. ${ }^{18}$ Recently tentative views on 'centralization' in the rural economy have been voiced. "With the development of the rural economy, a disadvantage of too much decentralization - i.e. that it restricts the development of the productive forces - is being gradually exposed". ${ }^{19}$ The author of the article in Guangming Ribao then gives reasons for his opinion:

First, the development of a commodity economy entails 'centralization' ... As a result of backward technology and backward management, more time will have to be spent on producing an individual product than is socially necessary and losses will be inevitable. In order to overcome the disadvantages of the peasants' decentralized operations, it is necessary to establish centralized service organizations which provide effective and efficient information, technical and management services for the peasants involved in decentralized operations....

Secondly, because of its special characteristics, agricultural production requires centralization. Natural conditions greatly affect agricultural production. In order to enhance the people's ability to cope with nature, it is necessary to group and organize the peasant households so that they can share water resources, work together to build irrigation works and so on.

Thirdly, socialized production calls for 'centralization'. The development of our commodity economy has led to a higher degree of the division of labour and a higher degree of specialization in rural areas. The more closely the peasants are tied to society, the more socialized production and management will be. In the course of agricultural production, some processes, such as the growing, purification and rejuvenation of seeds and seedlings and the drying, processing and transport of products must be handled by some specialized units which provide centralized services for peasant households.

Fourthly, 'centralization' is essential if we are to take the road of mutual prosperity. 
Investments for the modernization of agriculture have to come from the industrial sector of the economy, and thus the crucial issue of any further reform and development of the whole system is the functioning and progress of the industrial or modern sector of the Chinese economy.

\section{Problems of the Industrial Sector}

\section{The Reform Document of October 20, 1984}

The key document on reform of the economic structure is the decision of the Central Committee of the Communist Party of China, adopted by the 12th $\mathrm{CC}$ of the CPC at its third plenary session on October 20, 1984..$^{20}$ Though the title of the document refers to the 'economic structure', the document almost exclusively deals with the industrial sector of the economy, the 'urban economy'. In this document one finds sharp criticism of the state of industry being mainly the result of the internal disorder during the cultural revolution. The economic efficiency of urban enterprises, according to the document, was low, and losses and waste in production, construction and commodity distribution were high. The superiority of socialism had yet to be brought into full play. Apart from historical, political and ideological causes, a major economic cause for this was a rigid economic structure that could not meet the needs of the growing forces of production.

The Chinese economy should, according to the reform document, continue to be a planned economy, but parts of the economy should be regulated through market forces. Only the key industries should remain in the realm of command planning. The medium-scale industry should be steered by guidance planning, and the small enterprises, particularly in the service sector, should function according to the market forces of supply and demand. The law of value will play a prominent role. The socialist economy is "a planned economy on the basis of public ownership of the means of production", the law of value being "consciously applied". The difference between socialist and capitalist economy, as far as a commodity economy and the law of value are concerned, lies not - according to the document - in whether they are still functioning, but in the difference in ownership, in whether there is an exploiting class and whether the working people are masters of the state... Under socialist conditions, neither labour power nor land, mines, banks, railways and all other state-owned enterprises and resources are commodities. 
A host of further regulations is decreed. Among them are regulations concerning the price reform. There is no room here to deal with all these elements of reform and the repercussions they had and will have. Suffice it here to make a brief remark on price reform. Prices should reflect the values of commodities as determined by the supply and demand situation. It is extremely difficult to carry through a price reform in a sellers' market. Inevitably distortions will occur in such a situation, and the state is again and again compelled to interfere, for example, lest inflation should exert a disruptive influence and create social unrest. But the PRC cannot wait for a buyers' market to appear. The reform of the urban economy is envisaged to be instrumental in creating a buyers' market - certainly a dilemma.

The most important parts of the reform design are, first, the separation of government from enterprise functions and, secondly, regulations relating to the internal reform of the enterprises, various forms of economic responsibility systems and the principle of distribution according to work. The main role of the state is to establish the framework for the operations of the enterprises, namely opening up of resources, coordination, planning of key projects, supply of raw materials, establishment of long-term perspective plans, erection of infrastructural projects, etc. Furthermore, the enterprises as independent units

are to compete with each other in order to raise productivity and to make better use of scarce means.

Already in 1983 and in the first half of 1984, the enterprises had been given greater decision-making rights. The transfer of profits had been replaced by a tax system, the enterprises could produce above-quota products, fix the prices for these commodities and do the marketing on their own accounts, etc. These regulations were supplemented by the introduction of the economic responsibility system. Contracts are concluded between employees and enterprises wherein rights and duties of both parties are fixed. The bonus and premium system is coupled with production achievements, the wage system in general is being reformed.

A crucial issue of the reform is the leading personnel. Factory directors shall take the responsibility for most of the economic operations of the enterprises, of course supported by party leaders and the workers' congresses. The further success of the reform will predominantly depend on directors, managers or entrepreneurs of a Chinese type - whatever one chooses to call them. Therefore one has to take a closer look at this important stratum of the industrial society. 


\section{Excursion: Experiences of a 'German-Chinese' Factory Director}

On October 1, 1984, the German engineer Werner Gerich from Bretten was appointed general manager of the Wuhan diesel engine factory. The retired engineer, 66 years old, came to China under a programme of the German Senior Expert Service, an organization which sends, upon demand, retired experts into developing countries - with only a nominal salary. With the help of a so-called 'guidance group' Gerich carried out a thorough management reform which was extended to the workshops. Several leading cadres were sacked, work discipline and overall efficiency were considerably raised. Table 5 presents, in the second section, a survey of the results.

At first some of the staff voiced their annoyance at him, reproached him with his "German discipline" and accused him of wanting "to become the chief of the chiefs". ${ }^{21}$ But later on he was made honorary citizen of Wuhan, received by Zhao Ziyang, Yao Yilin etc. Now the Chinese media call him respectfully'Mr. Quality' and describe him as a 'model factory director'.

Under Gerich the Wuhan diesel engine factory did not import sophisticated means of production or equipment. The success was mainly achieved by strictly observing given rules and specifications, greater changes were only made in management organization and control. For example, Gerich found out that as a result of starting machines late and shutting them down early, each person wasted at least 70 minutes each day. Thus, the factory lost over 2,400 man-hours every day, which meant over 700,000 hours lost each year. ${ }^{22}$ This very case shows us that there is probably a large scope for rationalization in most of the Chinese enterprises. The egalitarian policy of the Mao era had led to slackness and indifference.

\section{Is a Chinese Entrepreneur in the Offing?}

Certainly a rejuvenation of the cadres has taken place in the reform era. To cite Doak Barnett, more than one million senior cadres recruited before 1949 have been retired, and $44 \%$ of the leading officials at the provincial level and close to half at the prefectural level has been replaced. ${ }^{23}$ But what about those cadres in the position of factory directors?

The Shanghai newspaper Wen Hui Bao carried a report on the first issue of Zhongguo Qiyejia (China's Entrepreneurs), in which the honorary chairman of the China Plant Directors' Work Research Society dealt with the characteristics Chinese entrepreneurs should possess. ${ }^{24}$ First - he wrote - they should possess long-range ideals and ambitions. Secondly, they should simultaneously grasp the building of material and spiritual civilization. Thirdly, they 


\section{Table 5. Wuhan Diesel Engine Factory: Structural Data and Performance Rates}

Structural Data

Established in

Number of workers and staff

Equipment (586 pieces valued individually at over 800 Yuan) of which:

- purchased in the 1960s

- purchased in the 1970s

- purchased in the early 1980 s

Performance Rates

Jan.-Nov.

Jan.-Nov.

1984

1985

Production volume

$100.00 \%$

$114.90 \%$

Above-quota profits

$100.00 \%$

$161.40 \%$

Casting rejects

$32.72 \%$

$12.44 \%$

Up-to-standard rates for

- first time test runs

$80.00 \%$

$95.50 \%$

- performance of components

- key components

n.a.

$100.00 \%$

Degree of cleanliness (ministry standard: $165 \mathrm{mg}$ )

n.a.

Consumption per horse power of

- oil (ministry standard $1.7 \mathrm{~g}$ )

- diesel (ministry standard $185 \mathrm{~g}$ )

Reworking rates (percentage changes as

compared with Jan.-Nov. 1984)

- block

- crankshaft

- cylinder head

- engine

$-71.93$

Sources: Fang Bi, "Zhuajin qiye neiwai de peitao gaige, shi gaohuo qiye de biyouzhilu" (Grasping firmly coordinated reforms both within and outside an enterprise is the only way to stimulate the enterprise), Jingji Guanli, No. 3 (1986), pp. 20-22; Qin Zhong, "Ge Lixi shi zenyang zhili 'Wuchai' de?" (How did Gerich put the Wuhan diesel engine factory in order?), Jingji Guanli, ibid., pp. 23-26.

should correctly handle relationships between the state, collective and individuals. Fourthly, they should correctly handle relationships between plant directors, party committees and workers' congresses. Fifthly, they should strive to acquire modern management knowledge.

According to this catalogue modern management knowledge seems to play a minor role. Much emphasis has been given to the correct handling of the relationships between the different levels. In the backbone enterprises, the large state-owned ones, the factory directors are mainly to represent the state..$^{25} \mathrm{In}$ 
the ordinary large and medium-sized enterprises, the factory directors are basically to represent the enterprises, and in the small enterprises that produce manufactured goods for daily use the factory directors are entirely to represent the enterprises. This hierarchy hints at the fact that the state will not give way to an independent stratum of entrepreneurs that could form a certain power basis.

Opposition against successful or enthusiastic managers comes from all levels. Numerous examples have recently been cited by the Chinese press. Thus a state-owned pland in $\mathrm{Xi}^{\prime}$ an which carried out a series of reform measures was harassed by "a work team sent by the departments in charge", which distracted people from their work in the factory and caused output to fall. ${ }^{26}$ On June 16, 1986, the People's Daily reported several cases in which innovative managers had been attacked. ${ }^{27}$ In almost all of these cases the managers, often under the pretext of minor mistakes, had been questioned by higher administrative authorities, whereas the workers backed them.

While the government in Beijing has pushed hard for application of the reponsibility system for factory directors, local party officials put up resistance against the new trend. ${ }^{28}$ Economic problems are indissolubly connected with political problems. It remains to be seen whether or not a stratum of really powerful managers can be formed. A new balance between political decisionmakers and economic leaders, between the traditional ideology-minded leaders and the pragmatic technocrats has to be found, and it is hoped that the development will not stop short to the disadvantage of the economic men.

\section{Summary}

This paper started with statistical evidence of the economic success of the reform era as compared with the time before 1976. The reform began in agriculture and had a tremendous success. A thesis advanced in that part of the paper was that the top decision-making elite released the agricultural sector to concentrate on the modern industrial sector. A large part of the agricultural success can probably be attributed to the effects brought about by the repair of shortcomings and deficiencies of the old system. Sooner or later agricultural yields will reach a plateau level, further improvement then can only be reached by increased productivity. Agricultural productivity can only be raised by massive investments coming from the industrial sector. The reform of the urban economy is an absolute necessity too. 
In the industrial sector, things are much more complex than in the countryside. The state has permanently to intervene even in the realm of economic process policy. Crucial issues such as the planning system, the price and wages reform, new developments in the finance sector, in the legal system, etc. could not be dealt with. The stratum of managers or entrepreneurs of a Chinese type is probably to play a leading role in the course of reform. But there is opposition against them from traditional power elites in the party or in the middle echelons of the economic planning system.

\section{NOTES}

1 Cheng Chu-Yuan, Economic Reform in Mainland China: In Comparison to Yugoslavia and Hungary, Issues and Studies, Vol. 19, No. 9 (Sept. 1983), p.29.

2 Cf. idem, China's Economic Development. Growth and Structural Change (Boulder, Colo. 1982), p. 355.

$3 \mathrm{Cf}$. Jonathan Unger, The Decollectivization of the Chinese Countryside: A Survey of Twenty-eight Villages, Pacific Affairs, Vol. 58, No. 4 (Winter 1985-86), p. $588 \mathrm{f}$. Cf. also for further evidence of the effects of Maoist policies the following case study: Anita Chan, Richard Madsen and Jonathan Unger, Chen Village: The Recent History of a Peasant Community in Mao's China, (Berkeley 1984), particularly chapter 9.

4 Cf. Jiri Kosta, The Chinese Economy from the Great Leap Forward to the Present Economic Reform: A Battle between Two Concepts, Economics, Vol. 34 (1986), p.99.

5 Cf. Jonathan Unger, The Decollectivization of the Chinese Countryside: A Survey of Twenty-eight Villages, op.cit., p. 593.

6 See Hongqi, 1980, No. 20, pp. 11-15; cf. Unger, op.cit., p. 586.

7 See Renmin Ribao, January 18, 1984; cf. Unger, op.cit., p. 587.

8 Ibid., p. 593.
9 Cf. the detailed statistical analysis in Rdiger Machetzki, Chinas Landwirtschaft: Wandel zur alten Form?, China aktuell (August 1986), pp. 498 ff., particularly pp. $508 \mathrm{f}$.

10 Ibid., p. $508 \mathrm{f}$.

$11 \mathrm{Cf}$. Thomas P. Bernstein, Reforming Chinese Agriculture, The China Business Review, March-April 1985, pp. 45 ff.

12 See Renmin Ribao, June 12, 1983.

13 Xue Muqiao, China's Socialist Economy (Beijing; Foreign Languages Press, 1981), p. 242.

14 Cf. Jingiixue Zhoubao, June 6, 1986, quoted in SWB, FE/8308/C1, July 7, 1986.

$15 \mathrm{Cf}$. for instance for the province of Jiangsu the survey by Li Kegang, Dangqian nongcun renmin gongshe jiti jingji fazhan zhong de jige wenti (Some problems in the present development of rural people's commune and collective economy), Jingii Kexue, 1981, No. 3, pp. $72 \mathrm{ff}$.

$16 \mathrm{Cf}$. the detailed calculations on this problem in Erhard Louven, Chinesische Wirtschaftsterminologie: Definitionen und Kompatibilitaetsproblems. Teil III, China aktuell, January 1984, pp. $31 \mathrm{ff}$.

17 Cf. Rdiger Machetzki, op.cit., p. 515.

18 Cf. James A. Gregor, Economic Reform 
in the People's Republic of China: The 'Detoxification' of Maoism, Asian Thought and Society, Vol. XI, No. 31 (March 1986), p. 13.

19 Cf. Guangming Ribao, September 7, 1986.

$20 \mathrm{Cf}$. Zhongyang Guanyu jingji tizhi gaige de jueding, Renmin Ribao, October 21, 1984.

21 Cf. Yu-hsi Nieh, Westliche Medizin, Welthandel, Vol. 5, No. 29 (October 11, 1985), p. 8.

22 Cf. Qin Zhong, Ge Lixi shi Zenyang zhili 'Wuchai' de? (How did Gerich put the
'Wuhan diesel' engine factory in order?), Jingji Guanli, 1986, No. 3, p. 25.

23 Cf. Doak A. Barnett, Ten Years after Mao, Foreign Affairs, Fall 1986, p. 47.

24 Cf. Wen Hui Bao, July 20, 1985, quoted in SWB, FE/8022/BII, June 8, 1986.

25 Cf. Guangming Ribao, November 2, 1985.

26 Cf. Radio Xi'an, Shaanxi, June 27, 1986, quoted in SWB, FE/8304/BII, July 7, 1986.

27 Renmin Ribao, June 16, 1986.

28 Cf. Asian Wall Street Journal, September $8,1986$. 

Copenhagen Papers in East and Southeast Asian Studies is published by the Center for East and Southeast Asian Studies, University of Copenhagen. It is a publication series devoted primarily, but not exclusively, to modern East and Southeast Asian Studies.

Forthcoming issues will include "Chinese Intellectual Life Post-Mao", "East Asian Security in the 1980s", "Decentralized Water Resource Management in the PRC", "Science and Technology Reforms in the PRC", "Reform and Readjustment in the Chinese Economy with Particular Reference to the Post-Mao Period", and "The Role of the State in the East Asian Modernization Process".

Manuscripts submitted to the editor should be typed double-spaced with footnotes at the end of the article. After manuscripts have been accepted, authors are encouraged to submit their final version on a $5^{1 / 4}$ inch diskette, preferably in a pure ASCIIcode.

(C) Center for East and Southeast Asian Studies,

University of Copenhagen, 1987

Layout by Thora Fisker

Printed by Special-Trykkeriet Viborg a-s

ISBN 87-7289-020-7

ISSN 0903-2703 